\title{
ARTICLES
}

\section{Restricting Biofuel Imports in the Name of the Environment: How Does the Application of WTO Rules Affect Developing Countries?}

\author{
Haniff Ahamat* \& Nasarudin Rahman**
}

There are calls for biofuel imports from developing countries to be restricted. The imports which are either in the form of end-product (bioethanol or biodiesel) or feedstock (oil palm, sugar cane molasses, etc) are allegedly produced in ways which can threaten the environment and violate human rights. This article finds that there is no specific regime for trade in biofuels within the WTO system. Hence any restriction on such trade is governed by the existing trade regimes including tariffs and nontariff measures. However, the existing WTO tariff and non-tariff (TBT, anti-dumping and anti-subsidy) regimes are still inadequate in ensuring that measures are taken against biofuel feedstock and products that were produced in unsustainable ways. The use of these measures without being subject to clear defining rules will create a danger that they serve a protectionist rather than social or environmental objectives.

\section{Keywords}

WTO law, international Environmental law, Renewable Energy, Like Products, Sustainable Development, Special \& Differential Treatment

* Assistant Professor at International Islamic University Malaysia ("IIUM") Ahmad Ibrahim Kulliyyah (Faculty) of Laws. LL.B. (IIUM), LL.M. (UKM), Ph.D. (Essex). ORCID: https://orcid.org/0000-0003-4026-3633. The author may be contacted at: ahaniff@iiu.edu.my/ Address: AT O. Box 10, 50728, Kuala Lumpur, Malaysia.

** Assistant Professor at International Islamic University Malaysia Ahmad Ibrahim Kulliyyah (Faculty) of Laws. LL.B., MCL (IIUM), Ph.D.(Macquarie). ORCID: http://orcid.org/0000-0003-3093-559. The author may be contacted at: nasarudin@iium.edu.my / Address: ATO. Box 10, 50728, Kuala Lumpur, Malaysia. 


\section{Introduction}

As the surge in global oil prices has increased the demand for production and trade of both biofuel feedstocks and products, trade in biofuels is becoming a more relevant topic of discussion in the international community. This has led to an increase in demand for crops, like soybean, corn and sugar cane, which is processed into not only biofuel feedstock, but also for biofuel end products like bioethanol and biodiesel. This has pressured supply, which has in turn led to the inflation of the prices of food. This can be witnessed in the skyrocketing prices of tortillas in Mexico, which was partly due to the lucrative demand for corn from bio-ethanol producers in the US. ${ }^{1}$ Food supply may be threatened by disincentives to farmers; they would rather focus on producing 'fuel-friendly' grains. As evidenced in the US, some farmers switched from wheat to maize for this purpose. $^{2}$

The mass production of biofuels could lead to the clearing of large tracts of rainforests. Grand scale developments of palm oil plantations in Malaysia and Indonesia, and sugar cane plantations in Brazil for the production of biofuels are vivid examples of devastation. They have led to deforestation, mono-cropping and the deprivation of human rights of indigenous people which is to be protected under the International Covenant on Economic, Social and Cultural Rights ("ICESCR") as well as the regional human rights treaties. Biofuel crop plantations disrupt communal living of the indigenous, deprive their right to health ${ }^{3}$ and deny their cultural rights. ${ }^{4}$ These arguments have been used consistently by developed countries as a means to restrict biofuel imports from developing countries like Malaysia, Indonesia and Brazil in that they inform the discussions on trade in biofuels. $^{5}$

1 Jo Tuckman, Tortilla turmoil, The Guardian, Aug. 22, 2007, available at http://www.guardian.co.uk/society/2007/ aug/22/guardiansocietysupplement.environment (last visited on Apr. 6, 2014).

2 J. Vidal, The looming food crisis, The Guardian, Aug. 29, 2007, available at http://www.guardian.co.uk/ environment/2007/aug/29/food.g2 (last visited on Apr. 6, 2014).

3 An example is Inter-American Commission on Human Rights case of Yanomami v. Brazil (Res. No. 12/85, Case 7615). See C. Scott, Multinational Enterprises and Emergent Jurisprudence on Violations of Economic, Social and Cultural Rights, in Economic, Social and Cultural Rights 577 (A. Eide, C. Krause \& A. Rosas eds., 2001); C-f. Lo, Plurilateral FTAs to Enhance Human Rights Protection in Asia, 8 Asian J. WTO \& InT'L Health L. \& Pol'y 608 (2013).

4 Scott, id. at 581 .

5 Friends of the Earth, The use of palm oil for biofuel and as biomass for energy: Friends of the Earth's position, Briefing, Aug. 2006, available at http://www.foe.co.uk/sites/default/files/downloads/palm_oil_biofuel_position.pdf (last visited on Apr. 6, 2014). See also A. Barber, G. Pellow \& M. de Pereira, The Sustainability of Brazilian Sugarcane Bioethanol: A Literature Review, May 2008, available at http://s3.amazonaws.com/zanran_storage/www.eeca.govt.nz/ 
A critical question now is how the WTO system should respond to such restrictions. This research is to examine the legal position of the trade of biofuels within the GATT/WTO system. This article is composed of six parts including short Introduction and Conclusion. Part two will analyse biofuel trade and the GATT/ WTO system. Part three will investigate the use of tariffs in biofuel trade. Part four will discuss the use of non-tariff measures in biofuel trade including technical barriers, anti-dumping, and anti-subsidy policies. Part five will touch upon the adequacy of the framework within the WTO system to safeguard the interests of developing countries in relation to their trade in biofuels.

\section{Trade in Biofuel and the GATT/WTO System}

There is no specific regime on the trade in biofuels within the WTO system. In theory, the WTO and its predecessor, the GATT are to promote non-discrimination through the Most Favoured Nation ("MFN") and National Treatment rules. Progressively, they reduce tariffs and introduce non-tariff measures ("NTMs"). However, several major obstacles to trade remain intact within the WTO system which can be found in the trade policy measures (both tariff and non-tariff). These measures are to be used by the WTO Member States on goods which have not been specifically classified as biofuels, but are classified as products which may or may not be used as biofuels (e.g. bio-ethanol and biodiesel).

The harmonised system ("HS") is universally used for product classification for both tariff and non-tariff purposes; but it does not have a specific nomenclature for biofuel products which are mainly in the form of bioethanol or biodiesel. ${ }^{8}$ The same applies to biofuel feedstocks, the primary products for producing bioethanol or biodiesel, e.g., oil palm and sugar cane molasses.

The conclusion of the Uruguay Round and the resulting establishment of the WTO have emphasized the need for the protection of the environment in both bilateral and multilateral trade negotiations. This is not surprising, given that the

ContentPages/16021933.pdf (last visited on Apr. 6, 2014).

GATT art. 1 .

7 M. Trebilcock \& R. Howse, The Regulation of International Trade 20 (2d ed. 1999).

8 A. Dufey, Biofuels Production, Trade and Sustainable Development: Emerging Issues 25 (International Institute for Environment and Development, 2006), available at http://pubs.iied.org/pdfs/15504IIED.pdf (last visited on Apr. 6, 2014). 
preamble to the Agreement Establishing the WTO states:

While allowing for the optimal use of the world resources in accordance with the objective of sustainable development, seeking both to protect and preserve the environment and to enhance the means for doing so in a manner consistent with their respective needs and concerns at different levels of economic development.

This preamble demands a more inclusive approach of the WTO so that the measures of the WTO Members reflect not only economic, but also environmental and social concerns. This would allow the WTO Members to restrict imports of biofuels, if the imports raise any relevant environmental and social concerns. However, there is a fine line between measures driven by a genuine environmental/social motive, and those by a merely protectionist motive. More importantly, a preamble does not hold a binding force, i.e., the preamble to the WTO Agreement is not binding on Member States.

There is another avenue for addressing environmental and social concerns arising from the biofuel trade. Article XX of the GATT provides general exceptions to the GATT/WTO rules which promote trade liberalization through specific measures to protect the environment with its two sub-paragraphs: (b) and (g). Article XX(b) allows trade restrictive measures if they are necessary to "protect human, animal or plant life or health." Article XX(g), on the other hand, allows such measures if they relate to the "conservation of exhaustion of natural resources if such measures are made effective in conjunction with restrictions on domestic production or consumption." However, invoking Article XX as a tool to protect the environment is not an easy task. There is a 'two-tier test' that must be executed by the State in order to rely upon Article XX. First, the Member State must determine that the measure falls under exceptions listed under sub-paragraphs (a) to (i) of Article XX. Second, it must fulfil the requirements of the chapeau to Article XX. ${ }^{9}$

Regarding the first component of Article XX, i.e., the sub-paragraphs (a) through (g) of Article XX enshrine the legitimate policy objectives that Member States can resort to the general exceptions as provided, so that the requirements contained in Article XX are met. ${ }^{10}$

However, Article XX (b) of the GATT requires another test (three-tier): (1) the policy objective pursued by the relevant measure is the protection of life and health; (2) the measure is necessary to fulfill that policy objective; and (3) the measure was

9 Appellate Body Report, US-Shrimp ๆ 120, WT/DS58/AB/RW (Oct. 22, 2001).

10 Id. 
applied in conformity with the requirements of the introductory clause of Article XX. ${ }^{11}$ The third-tier of the test refers to the chapeau which will be discussed later in this paper.

The first tier covers public health and environmental policy measures. The right to health may be included as a means of justification targeting biofuels on grounds of environmental and public health concerns. It is necessary for States to apply these measures to show that there are health risks to human, plants and animals. ${ }^{12}$ The second tier shows that the measures are necessary to protect the life or health of human, plants, and animals.

As established in the US-Gasoline case, it must be proved that a GATT/WTO consistent alternative is not reasonably available. ${ }^{13}$ This imposes a high standard of proof on States whereby, for any measure to be justified on the grounds of protection of human, animal, plant life or health (which includes the environment), there must be no other alternative measure available which can achieve environmental protection in a less trade-restrictive way. ${ }^{14}$ Article $\mathrm{XX}(\mathrm{g})$, however, does not require the necessity test. Instead, for a measure to be justified under that sub-paragraph, the test used is 'related to' which has been interpreted to mean "primarily aimed at." ${ }^{15}$ In other words, Member States are obliged to ensure that the measure in question must primarily be aimed at conserving natural resources, but are not obliged to fulfil all elements of such a necessity.

Despite the different standards of policy objectives imposed by Article XX(b) and (g), importing countries intending to impose restrictions on biofuel imports for protection of the environment or human rights bear the burden of proof that all elements from both provisions are satisfied. This is apart from the second component of Article XX that is the chapeau. ${ }^{16}$

In US-Shrimp, the Panel noted that the purpose of the chapeau is to prevent abuse of the exceptions so that "a balance must be struck between the right of a Member to invoke an exception under Article XX and the duty of that same Member to respect

11 Panel Report, US-Gasoline 9 6.20, WT/DS2/R (Jan. 29, 1996). [Emphasis added]

12 In Thailand-Cigarettes, e.g., smoking posed a serious risk to human health. Those measures to reduce cigarettes consumption were found to fall under GATT XX(b).

13 Supra note 11, ๆ 89.

14 In EC-Asbestos, the Appellate Body referred to United States - Section 337 of the Tariff Act of 1930 (GATT Panel Report) which found that a measure is necessary "if an alternative measure which [a Member] could reasonably be expected to employ and which is not inconsistent with other GATT provisions is [not] available to it." See Appellate Body Report, EC-Asbestos $\uparrow$ 62, WT/DS135/AB/R (Mar. 12, 2001).

15 For this definition, see Appellate Body Report US-Gasoline $₫$ 18, WT/DS2/AB/R (Apr. 29, 1996).

16 Supra note 11. 
the treaty rights of the other Members." ${ }^{17}$ The chapeau requires the measure not to constitute a means of arbitrary or unjustifiable discrimination between countries where the same conditions prevail, ${ }^{18}$ or a disguised restriction on international trade. It must be noted that the chapeau does not prevent every incident of discrimination. However, any discrimination will be arbitrary or unjustifiable if it does not permit inquiry into the suitability of the measure due to different conditions in the exporting country, regardless of whether the prohibition on inquiry is important to achieve a policy goal. ${ }^{19}$ An importing country may thus impose similar regulations on local and foreign products. If the regulations do not consider the different conditions in the exporting country, however, there is a possibility of being arbitrary and unjustifiable discrimination arising from these regulations. The second element of the chapeau is that the measures must not be a disguised restriction on international trade. ${ }^{20}$ In US-Gasoline, the Appellate Body held that:

\begin{abstract}
'Arbitrary discrimination,' 'unjustifiable discrimination' and 'disguised restriction' on international trade may, accordingly, be read side-by-side; they impart meaning to one another. It is clear to us that 'disguised restriction' includes disguised discrimination in international trade. It is equally clear that concealed or unannounced restriction or discrimination in international trade does not exhaust the meaning of 'disguised restriction. $^{21}$
\end{abstract}

Some developed countries have introduced policies to protect the environment; the implementation of these policies has impeded the flow of biofuel products made from certain crops into those countries. One of the examples of these policies is the European Union's Renewable Energy Directives (“RED”) of 2009, ${ }^{22}$ which was used against biofuels made from oil palms.

As discussed above, Article XX contains stringent tests which are tedious for developed countries since they must prove that the environmental measures are

17 Appellate Body Report, US-Shrimp 1 156, WT/DS58/AB/R (Oct. 12, 1998). [Emphasis added]

18 The word, 'discrimination' here refers to those between all exporting countries and discrimination between the exporting country and the importing country. See id. $\uparrow 150$.

19 That is why in US-Shrimp, the exclusion of shrimp harvested in waters of countries not certified by the US from the US market, despite the relevant shrimp trawl vessels using turtle exclusion devices as required by the US pro-turtle measure, was held to be inconsistent with Article XX of GATT. See supra note 17, US-Shrimp, qฯ 164-165.

20 GATT art. XX.

21 Appellate Body Report, US-Gasoline $\llbracket 25$, WT/DS/2/AB/R (Apr. 29, 1996).

22 See European Parliament and the Council, Directive 2009/28/EC (Apr. 23, 2009); Directives 2001/77/EC \& 2003/30/ EC, OJ L 140/16, available at $\mathrm{http}: / /$ faolex.fao.org/cgi-bin/faolex.exe?rec_id=071840\&database=faolex\&search_type= link\&table=result\&lang=eng\&format_name=@ERALL(last visited on Apr. 6, 2014) 
drawn upon an established risk on human, animal and plant's life or health and that there is no other less trade restrictive alternative reasonably available. It has been argued that a less trade restrictive alternative is available as the RED 2009 "excludes biofuels made from raw materials obtained from land with high biodiversity regardless of whether the land continues to have that status. ${ }^{23}$ It is probable that a land loses its biodiversity for reasons other than biofuel production and the biofuels sourced from areas will still be penalized. ${ }^{24}$ If they adopt the measures because of the need to conserve natural resources (which may include clean air), ${ }^{25}$ they only have to establish the relevance of the measures to such an objective. ${ }^{26}$ Nevertheless, countries using measures such as the RED 2009 have to fulfill the requirements of the chapeau to Article XX of the GATT. ${ }^{27}$

\section{The Use of Tariffs}

\section{A. Tariff Escalation}

The GATT/WTO tariff regimes have progressively reduced tariffs on various types of goods. In fact, most developed countries have maintained low tariff rates particularly on industrial goods. ${ }^{28}$ This has benefitted developing countries in terms of improving market access to goods from those countries. However, there are valid concerns with respect to the use of tariffs by developed countries against biofuel imports from developing countries through 'tariff escalation.'

Tariff escalation prevails in developed countries. It is when an importing country imposes higher import duties on semi-processed products than on raw materials. ${ }^{29}$

23 A. Mitchell \& C. Tran, The Consistency of the EU Renewable Energy Directive with the WTO Agreements, Georgetown Business, Economics \& Regulatory Law Research Paper No. 1485549 (Oct. 2009), at 9, available at http://scholarship.law.georgetown.edu/cgi/viewcontent.cgi?article=1121\&context=fwps_papers (last visited on Apr. 6, 2014).

24 Id.

25 In US-Gasoline, the Panel did refer clean air as something that was covered by the term 'natural resources.' See supra note $11, \boldsymbol{q} 6.37$.

26 Supra note 15.

27 Supra note 12.

28 B. Hoekman, F. Ng \& M. Olarreaga, Eliminating Excessive Tariffs on Exports of Least Developed Countries, Policy Research Working Paper No. 2604, World Bank Development Research Group, (May 2001), at 1, available at http:// www-wds.worldbank.org/external/default/WDSContentServer/IW3P/IB/2001/06/23/000094946_01061405084793/ additional/118518322_20041117140538.pdf (last visited on Apr. 6, 2014).

29 WTO, Glossary, available at http://www.wto.org/english/thewto_e/glossary_e/glossary_e.htm (last visited on Apr. 6, 
The duties can be higher on finished products. ${ }^{30}$ The aim of tariff escalation is to prevent countries which produce and export raw materials from being able to produce and export goods with a higher value-added. ${ }^{31}$ Since the developed countries have long monopolized manufacturing and processing technologies, the practice of tariff escalation would protect their domestic producers while inhibiting efforts by developing countries to venture into higher-end industries or other economic activities that reduce their dependency on the commodity and agricultural sectors for national income.

In the context of trade in biofuels, developed countries prefer higher tariff rates on biodiesel or bio-ethanol to those on oil palm or sugar cane molasses so that raw materials for biofuel may be readily available at low prices to domestic producers. ${ }^{32}$ In contrast, they do not want the competing producers in developing countries to benefit from equally low tariff lines. This is why the prices of biofuels would remain high in developed countries' markets.

\section{B. Tariff Peaks}

Resorting to tariff peaks is common. Tariff peaks take place especially when a WTO Member has to convert quantitative restrictions (quotas) on its imports into tariffs (tariffication). ${ }^{34}$ Tariffication has become a norm since Article XI of the GATT prohibits quantitative restriction and GATT Contracting Parties (equivalent to Member States of the WTO) agreed to give effect to the above-mentioned conversions hence leading to the excessively high tariff rates for certain types of products, particularly agricultural. ${ }^{35}$

Developed countries are committed to reducing tariff rates on imported goods from developing countries whose processes are undertaken both multilaterally and

2014).

30 Id.

31 B. Das, The World Trade Organisation: A Guide to the Framework for International Trade 69 (1999).

32 This was practiced by the EU when facing pressures from domestic producers so that a higher tariff rate was imposed on bio-ethanol imports from Pakistan than on raw molasses causing closure of bio-ethanol plants there. See supra note 8 , at 25 .

33 Id. at 26.

34 Id. at 29.

35 A study by the UN Conference on Trade and Development ("UNCTAD") reveals that developed countries like Canada, Japan, the EU and the US maintained tariff rates as high as $360 \%$ for butter (Canada), $213 \%$ for beef (EU), $388.1 \%$ for wheat products (Japan) and $244.4 \%$ for sugar (US). See UNCTAD, TD/B/WG.8/2/Add.1 (July 26, 1995), Table I.1, recited from supra note 31, at 232, available at http://www.isgmard.org.vn//nformation\%20Service/Report/ Agriculture/General\%20report-WTO-e.pdf (last visited on Apr. 9, 2014). 
bilaterally. ${ }^{36}$ Whether such commitments also extend to biofuel imports depend on the willingness of developed countries to address the issues of tariff escalation and tariff peaks which also affect biofuel products.

\section{The Use of Non-Tariff Measures}

Non-tariff measures ("NTMs") are the other means by which developed countries can limit export of biofuel products by developing countries. This article identifies two relevant types of NTMs - technical barriers to trade ("TBT") - and anti-dumping policy.

\section{A. Technical Barriers to Trade}

TBT is reflected in regulations on products based not only on their features when they reach the end-users, but also on how they are processed. Such regulations contain technical regulations, standards, and conformity assessments including packaging, labelling, water and electricity efficiency criteria, etc. ${ }^{37}$

In the context of trade in biofuels, developed countries have applied specific regulations against those biofuels which are produced and processed in ways that do not satisfy certain standards contained in the regulations. ${ }^{38}$ Such standards may require imported biofuels to be sourced and processed in environment-friendly ways, whereas 'tropical' biofuels produced from oil palm or sugar cane can be restricted of their access into the markets of some developed countries. ${ }^{39}$ There have been several emerging environmental issues including the clearing of rainforests in,

36 B. Balassa, Trade between Developed and Developing Countries: The Decade Ahead, at 8-10, available at http://www. oecd.org/eco/growth/2501905.pdf (last visited on Apr. 6, 2014).

37 TBT Agreement annex 1. It defines technical regulation as "document which lays down product characteristics or their related processes and production methods, including the applicable administrative provisions with which compliance is mandatory. It may also include...packaging, marking or labeling requirements..." The same annex defines standard as "document approved by a recognized body, that provides for...rules, guidelines or characteristics for products or related processes and production methods, with which compliance is not mandatory. It may also include terminology, symbols, packaging, marking or labeling requirements as they apply to a product, process or production method." Finally it defines conformity assessment procedure as "any procedure used, directly or indirectly, to determine that relevant requirements in technical regulations or standards are fulfilled." [Emphasis added].

38 World Energy Council, Biofuels: Policies, Standards and Technologies18 (2010), available at http://www. worldenergy.org/documents/biofuelsformatedmaster.pdf (last visited on Apr. 6, 2014).

39 A. Campbell \& N. Doswald, The Impacts of Biofuel Production on Biodiversity: A Review of the Current Literature 21 (2009). 
e.g., Malaysia, Indonesia and Brazil as well as their transformation into oil palm and sugar cane plantations. As the horizons of the biofuel debate widen, more premises for restricting access to such types of biofuel emerge in support of TBT regulations including the effects of imported biofuels on food security, energy security or other technical grounds. The WTO TBT regime has its own elaborate rules on technical regulations, standards and conformity assessment procedures. This regime purportedly strives to hit a balance between prevention of protectionism and respect for the right of the WTO Members to make domestic policies on products for certain public policy purposes. ${ }^{40}$ It is nevertheless, a growing concern that the TBT measures are becoming a merely protectionist tool by the WTO Members which have committed to reducing their reliance on tariffs. ${ }^{41}$

Today, the WTO is scrutinizing the Renewable Energy Directive 2009 [hereinafter RED 2009], the relevant EU legislation concerning this area. Article 3 of RED 2009 requires Member States to place mandatory national overall targets for the energy use from renewable resources including a specific target for the share of energy from renewable resources used in transport. ${ }^{42}$ The targets ask the EU Member States to ensure that at least 20 percent of its gross final consumption of energy in 2020 will have to come from renewable resources. RED 2009 also places a target in the share of renewable resources in the final consumption of energy in transport in 2020 that 10 percent of such consumption will have to come from renewable resources. ${ }^{43}$

These targets do not impose any barriers on trade in biofuels by themselves. Rather, they are likely to increase the demand for products, thereby increasing their production and trade. However, there are sustainability criteria that must be met by producers in order to comply with the national targets and other renewable energy obligations, and to be eligible for the financial support provided for in the directive.

The criteria are reflected in Article 17.3 of RED 2009 which provides that the biofuels to be achieved in the national targets must not be acquired from raw materials obtained from lands with a high biodiversity value. ${ }^{44}$ Such land includes

40 R. Steinberg, Trade-Environment Negotiations in the EU, US and WTO: Regional Trajectories of Rule Development, 91 Am. J. InT'L L. 240 (1997). See also J. McDonald, Domestic Regulation, International Standards, and Technical Barriers to Trade, 4 World Trade Rev. 270 (2005), recited from C. Gibson, Globalization and Technology Standards Game: Balancing Concerns of Protectionism and Intellectual Property in International Standards, 22 BERKELEY TECH. L. J. 1464(n. 315)(2007); C.S. Gibson, A New and Controversial Mandate for the SPS Agreement: the WTO Panel's Interim Report in the EC Biotech Dispute, 32 Colum. J. EnvTL. L. 291 (2007).

41 A. Gibson, Supermarket Labels and the TBT Agreement: 'Mind the Gap,' available at http:/www.wcl.american.edu/ blb/04/1 appleton.pdf?rd=1 (last visited on Apr. 6, 2014).

42 Supra note 21.

43 RED art. 3.4.

44 Id. art. 17.3. 
those covered in primary forest with no clear and visible human activity and whose ecological processes are not significantly disturbed. The same provision precludes from the national targets for biofuels made from raw materials obtained from land with high carbon stock. Such lands are as follows: (1) wetlands; (2) continuously forested areas - land spanning more than 1 hectare with trees higher than 5 meters and a canopy cover of more than 30 percent; and (3) land spanning more than one hectare with trees higher than 5 meters and a canopy cover of between 10 percent and 30 percent.

What will be influenced most by RED 2009 are biofuel feedstocks produced from plants cultivated in tropical rainforests because these areas fit with the land statuses as described in Article 17.3. Further, RED 2009 also requires biofuel products to emit 35 percent less greenhouse gas than fossil fuels in order to qualify for tax benefits provided for in the directive. ${ }^{45}$ From the WTO perspective, RED 2009 would create technical regulations affecting biofuel production and trade, an area governed by the TBT Agreement. ${ }^{46}$

Could the producers of tropical biofuel feedstocks then place a strong argument that the EU has violated the TBT Agreement? The EU regulations may fall into the category of technical regulations. Article 2.2 on technical regulations of the TBT Agreement provides that:

\footnotetext{
Members shall ensure that technical regulations are not prepared, adopted or applied with a view to or with the effect of creating unnecessary obstacles to international trade. For this purpose, technical regulations shall not be more trade-restrictive than necessary to fulfil a legitimate objective, taking account of the risks non-fulfilment would create. Such legitimate objectives are, inter alia: national security requirements; the prevention of deceptive practices; protection of human health or safety, animal or plant life or health, or the environment. ${ }^{47}$
}

If RED 2009 is in line with the TBT Agreement, a two-step analysis needs to be made. First, it must be for a legitimate objective; protection of the environment is one of the legitimate objectives mentioned in Article 2.2. ${ }^{48}$ Second, it must not be more traderestrictive than necessary, taking into account the risks that will emerge from the

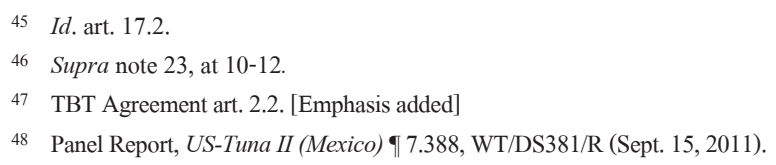


non-fulfilment of the objective. ${ }^{49}$ There is a question as to whether the necessity test of Article 2.2 is similar to that in Article XX(b) of the GATT. In US-Tuna II (Mexico), the Panel, distinguishing them, stated that the former refers to "technical regulations that are more trade restrictive than necessary to fulfil a legitimate objective," whereas the latter refers to 'measures necessary' to protect public morals, to protect human, animal or plant life or health. ${ }^{50}$ Consequently, under the TBT Agreement, technical regulations like the RED 2009 are still allowed to be trade-restrictive. However, such trade-restrictiveness is necessary for the fulfilment of the objective. This is in contrast with Article $X X(b)$ of the GATT which requires the non-existence of a WTO-consistent alternative that can achieve the mandated objectives; the WTOinconsistent measures are required to achieve the objectives. ${ }^{51}$

A question may remain as to whether the trade-restrictive nature or the effect of the RED 2009 is the best way to achieve its objective of a TBT measure for environmental protection. The last limb of Article 2.2 of the TBT Agreement (taking account of the risks non-fulfillment would create) would allow Member States to consider the likelihood and gravity of potential risks of the non-fulfilment of the objective. ${ }^{52}$ In the context of RED 2009, the scientific and technical evidence that prove oil palm as a cause of environmental damage are likely to increase the burden on palm oil producers.

Whether technical decisions can be made and enhanced objectively by such criterion remains unsettled, especially because there is a possibility that the scientists of the WTO Member States could manipulate the facts and findings under the garb of national interest.

The restrictions on biodiesel imports produced from oil palms whose cultivations deleteriously affect the environment may easily fall under the legitimate objectives. As the following Table shows, however, the biofuel feedstocks from tropical plant yield greater volume of biodiesel per hectare/acre than those from temperate climate. (Figure 1)

As illustrated above, biofuel feedstocks grown in temperate areas generally produce less oils/fats per acre/hectare compared to those grown in subtropical and tropical areas. The crop with the highest yield per acre/hectare is in fact oil palm. Ironically, oil palm is one of the most sensitive biofuel crops. According to

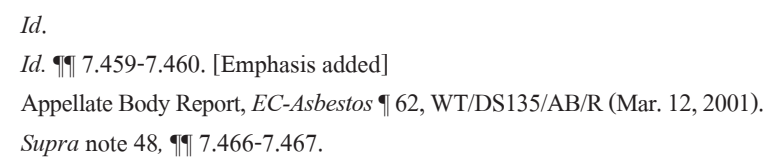


Figure 1: Biofuel crops' yield of oil per hectare/acre ${ }^{53}$

\begin{tabular}{|c|c|c|}
\hline Crop & Litres oil/hectare & US gallon/acre \\
\hline Corn & 172 & 18 \\
\hline Cashew nut & 176 & 19 \\
\hline Oats & 217 & 23 \\
\hline Cotton & 325 & 35 \\
\hline Hemp & 363 & 39 \\
\hline Soybean & 446 & 48 \\
\hline Linseed (flax) & 478 & 51 \\
\hline Hazelnut & 482 & 51 \\
\hline Pumpkin seed & 534 & 57 \\
\hline Sunflower & 952 & 102 \\
\hline Rapeseed & 1190 & 127 \\
\hline Olive & 1212 & 129 \\
\hline Castor bean & 1413 & 151 \\
\hline Pecan nut & 1791 & 191 \\
\hline Jojoba & 1818 & 194 \\
\hline Jatropha & 1892 & 202 \\
\hline Macadamia nut & 2246 & 240 \\
\hline Brazil nut & 2392 & 255 \\
\hline Avocado & 2638 & 282 \\
\hline Coconut & 2689 & 287 \\
\hline Oil palm & 5950 & 635 \\
\hline
\end{tabular}

environmentalists, producing countries like Malaysia and Indonesia have converted rainforests into oil palm plantations posing a threat to biodiversity. A forest area in Indonesia as big as England and Wales combined is reportedly under the threat of being cleared and replanted with oil palms. ${ }^{54}$

Studies have also shown that biofuel feedstocks and products relevant to tropical (developing) countries can have positive effects on the environment and the society. Tropical biofuel crops are more energy efficient than crops grown in temperate

53 See Oil yields and characteristics, available at http://journeytoforever.org/biodiesel_yield.html (last visited on Apr. 6, 2014).

54 Id. at 3. 
climate. ${ }^{55}$ Such crops also require less irrigation due to the abundant rainfall in tropical countries. ${ }^{56}$ All these findings must be accounted for, within the risk assessment exercises by the relevant national TBT authorities.

The TBT regimes (both international and domestic) must also address the difficulty of tracing the origins and sources of biofuel feedstocks and products. Biodiesel produced from palm oil is actually alike regardless of its origin sustainable and unsustainable plantations - so that feedstock from various sources may be mixed into the oil while processing into biodiesel ${ }^{57}$

Most of the WTO Members have enacted technical regulations and laws which require the country of origin for particular products to be identified. ${ }^{58}$ In responding to the possible mixture of biofuel feedstock from different sources, a certification system was devised to track the origin of palm oil biofuel. If it thus comes from a forest, e.g., the oil will not be certified. ${ }^{59}$

Finally, a question may arise as to whether the TBT Agreement reaffirms the respect for non-discrimination rules. Article 2.1 of the TBT Agreement prevents States from treating the product from one country less favorably 'like products' of national origin or originating in other Members. ${ }^{60}$ RED 2009 would arguably discriminate biofuel products made from tropical crops and non-tropical crops as the land statuses that exclude a biofuel product from classification as a renewable source of energy are indicative of tropical rainforest only. ${ }^{61}$ The 35 percent threshold of greenhouse gas emission also proves as a disadvantage to palm oil against rapeseed oil (which is produced by EU producers) because the later offers a greater

55 Supra note 8, at 40. See also I. Macedo, Converting Biomass to Liquid Fuels: Making Bioethanol from Sugar Cane in Brazil, in Energy As An Instrument for Socio-Economic Development (J. Goldemberg \& T. Johansson eds. 1995).

56 Supra note 8 , at 41.

57 In Biodiesel from US (EC anti-dumping case), the EC Commission highlighted its finding that biodiesel 'blends' may be derived from different types of raw material or production process but they still have similar basic physical, chemical and technical characteristics and are used for the same purposes. See Biodiesel from the US, [imposition of definitive anti-dumping duty], ๆ 23, OJ 2009 L179/26 (Reg. 599/2009), available at http://rade.ec.europa.eu/doclib/docs/2009/ july/tradoc_143986.AD.def.en.L179-2009.pdf (last visited on Apr. 9, 2014).

58 E.g., Article 17 of Act Governing Food Sanitation 2007 (Taiwan), Farm Bill 2008 (US), etc.

59 The certification program is part of the Roundtable for Sustainable Palm Oil ("RSPO") project. See UK Department for Environment, Food and Rural Affairs UK Statement on Sustainable Palm Oil: 1 Year on Progress Report, Nov. 2013, at 1, available at https:/www.gov.uk/government/uploads/system/uploads/attachment_data/file/259839/pb14061-palmoil-progress-report-131120.pdf (last visited on Apr. 9, 2014).

60 TBT Agreement art. 2.1.

61 D. Laborde, Assessing the Land Use Change Consequences of European Biofuel Policies Final Report, ATLASS Consortium, Oct. 2011, at 14, available at http://trade.ec.europa.eu/doclib/docs/2011/october/tradoc_148289.pdf (last visited on Apr. 9, 2014). 
savings in emissions calculations. ${ }^{62}$

Another question is whether both oils (palm oil and rapeseed/soy bean oil) are 'like products'? There is no consistent method for determining the likeness of the compared products. 'Likeness' may depend on tariff classification so that domestic products and imports under similar tariff headings will be considered like products. ${ }^{63}$ However, the products may fall under different headings and yet they may have similar product characteristics or end-uses. This is true as far as biofuel products are concerned because there is no clear tariff classification for biofuels yet. Considering that the bodies have also analyzed the characteristics of the products as well as the functions performed by them in determining the 'like product,' biodiesel produced from palm oil, and bioethanol produced from rapeseed oil may be thus regarded as 'like products.' Meredith has affirmed this tendency in his analysis of the possible outcome if Malaysia challenges the WTO-consistency of RED at the WTO dispute settlement body. ${ }^{64}$

However, the last method that Meredith explains is the "directly in competition or substitution" ("DCS") test or 'economic likeness' method. Meredith has also referred to it as the "cross-price elasticity of demand," ${ }^{65}$ which means that the change in the quantity demanded of a given (domestic) product is due to the change in the price of another (imported) 'related' product. ${ }^{66}$ Where the rise of the domestic products price leads to an increasing demand for imported products, they would be both competitive and substitutable. In that case, they would be considered as 'like products. ${ }^{97}$ Meredith shows that an economic analysis of supply-demand relationships may lead to the possibility that palm oil is not a substitute only for rapeseed oil. ${ }^{68}$

Meredith's position is consistent with the WTO jurisprudence on the matter. However, an impending issue may arise as to whether the term, 'like product' in

62 RED 2009/28/EC annex V. The value for palm oil was put at 19\% which according the African-American Environmentalist Association as a distorition because considering the multiple uses of palm oil kernels and other parts of the palm oil trees, the value may go up to as a high as $79 \%$, if pal oil is produced without methane capture. See Palm Oil: Determination of GHG contributions by subsystems in the oil palm supply chain using the LCA approach, available at http://cfece.org/PalmOilAAEA.htm (last visited on Apr. 6, 2014)

63 Appellate Body Report EC-Asbestos, WT/DS135/AB/R (Mar. 12, 2001).

64 M. Meredith, Malaysia's World Trade Organization Challenge to the European Union's Renewable Energy Directive: An Economic Analysis, 21 PAC. RiM L. \& POL’y J. 399-426 (2012).

65 Id. at 409.

66 See OECD Glossary of Statistical Terms, available at http://stats.oecd.org/glossary/detail.asp?ID=3185 (last visited on Apr. 6, 2014).

67 Supra note 65 , at $411-412$.

68 Id. at $410-417$. 
the TBT Agreement employs the same definition as laid down under Article III:4 of GATT 1994 (provision on national treatment). Two contrasting explanations emerge from the following cases.

In US-Clove Cigarettes, first, the WTO Panel rejected the argument that a 'competitive relationship' between two products should become the basis for 'likeness' in Article 2.1 of the TBT Agreement. ${ }^{69}$ Instead, the WTO Panel viewed that attention had to be paid to "the significance of the public health objective of a technical regulation. It also emphasized on how certain features of the relevant products, their end-uses as well as the perception consumers have about them, must be evaluated in light of that objective. ${ }^{70}$ In that case, the legitimate public health objective of the impugned US measure, to reduce youth smoking, was considered by the Panel in its likeness analysis. The Panel held that the imported clove cigarettes could still be 'like products' although they were not in competition with locally manufactured cigarettes, as both were forms of smoking. ${ }^{71}$

Nonetheless, in US-Tuna, second, the WTO Panel, referring to an Appellate Body ruling in EC-Asbestos, referred to a different language to give itself the option between the narrow and broad interpretations of likeness depending on the context of a case. ${ }^{72}$ More importantly, these narrow or broad interpretations entitled the Panel to consider the dynamics of competitive relationships particularly between local and imported products. This is also the case regarding the likeness analysis in Article III:4 of the GATT $1994 .^{73}$

If the second reasoning is applied to analyze the WTO-consistency with RED $2009,{ }^{74}$ it is possible for Meredith's conclusion (palm oil is not in a competitive relationship with locally produced rapeseed oil) to inform whether, by targeting specific types of biofuel crops grown in some countries (e.g. palm oil), the EU does not treat those products no less favorable than like products of national origin.

\section{B. Anti-Dumping Policy}

The anti-dumping policy can be used by developed countries against imports of biofuel from developing countries. It is a response to the practice of dumping which

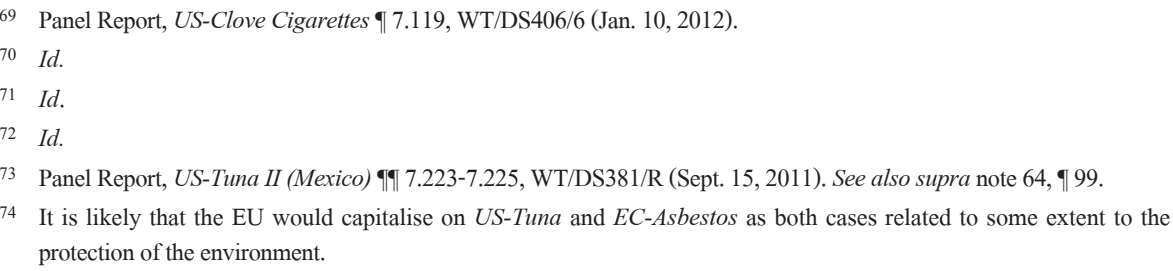


causes material injury to the domestic producers of the importing country. Dumping is selling in the export market at a price below normal value. ${ }^{75}$ Normal value is calculated on the basis of price differentials between the exporting and importing countries. ${ }^{76}$ If the prices of the imports are below costs, the normal value would be constructed. The purpose of penalizing a dumping exporter is to protect domestic producers from the low prices of the 'like product' in the importing country. ${ }^{77}$

In the context of trade in biofuels, anti-dumping policy may be favoured by developed countries since imports of biofuel from developing countries can be made available at much lower prices. Such a policy can target these practices as the conversion of rainforests into plantations or the payment of very low wages to workers. They have adverse social and environmental impacts within developing countries, but they allow the goods there to be produced and sold at cheaper prices.

Article VI of the GATT provides measures against two types of trade practices, i.e., dumping and subsidies. ${ }^{78}$ Examples of such measures are antidumping and countervailing duties, respectively. However, one must note that the latter regime (countervailing) is less significant than the former (anti-dumping) due to low frequency of countervailing cases. Additionally, developing countries are not expected to rely too much on subsidies to make their producers competitive in the international market. ${ }^{79}$ In this case, the subsidies involved are likely to be nonactionable. ${ }^{80}$ Hence, the countervailing regime is excluded from this discussion.

Dumping is condemned not only because it causes inefficiency, but also because it leads to market asymmetries; it gives foreign producers an advantage over domestic producers. ${ }^{81}$ Market asymmetries are contemplated in the closure of the dumping market due to high tariffs, restrictive business practices or government aid. These conditions facilitate foreign producers to cross-subsidize their export

75 Anti-Dumping Agreement art. 2.1.

76 Id. art. 2.2 .

77 For details on the debate of the pros and cons regarding anti-dumping measures, see T. Stewart \& T. Brightbill, Some 'Heretical' Observations on the Interaction of US Trade and Competition Laws: A Defense of US Antidumping and Countervailing Duties, 4 US-Mexico L. J. 35-48 (1996); R. Cass \& R. Boltuck, Antidumping and Countervailing Law: The Mirage of Equitable International Competition, in 2 Fair Trade and Harmonization: Prerequisites for Free Trade? 395-401 (J. Bhagwati \& R. Hudec eds. 1997); J. Kempton, Anti-Dumping and the Consumer Interest, 10 Consumer Pol'y Rev. 212 (2000); A. Holmes \& J. Kempton, Study on the Economic and Industrial Aspects of AntiDumping Policy, SEI Working Paper No. 22, University of Sussex European (1997).

78 GATT art. VI, 9 甲 2-3.

79 C. Raghavan, Call for Revision of Anti-dumping, Subsidy Rules, Third World Network, available at http://www. twnside.org.sg/title/dump-cn.htm (last visited on Apr. 6, 2014).

80 Id.

81 Holmes \& Kempton, supra note 77, at 13. 
sales, which, in turn, cut down prices in the importing market finally leading to the demise of the domestic producers. ${ }^{82}$ The 'fairness' theorists of anti-dumping measures argue that such 'unfairness' is the reason for the domestic producers not being able to produce efficiently and are hence driven out of the market. ${ }^{83}$ 'Fairness' can also be used against the asymmetries in environmental and labor standards for the production of the importing and the exporting (dumping) country. ${ }^{84}$ Low environmental and labor standards in the production of the goods in question in the exporting country, allow them to be dumped. In this context, the term, 'social/ environmental dumping' was coined by international trade lawyers and economists in order to justify measures against imports from developing countries including those of biofuel products. ${ }^{85}$

Another question is whether the WTO system accommodates social/environmental dumping. Can the anti-dumping regime under such systems allow the restriction of imports from developing countries (including those of biofuel products) in the name of protecting the environment or promoting other social objectives like labor standards?

Alben argues that substandard labor practices as one of the criteria of social dumping is included in the definition of dumping as laid down at Article VI of the GATT (which sanctions dumping) because such practices are unfair. ${ }^{86}$ Similarly, Fletcher maintains that if improving environmental standards in production could serve a level-playing-field purpose, the so-called eco-dumping or environmental dumping should be part of the WTO anti-dumping regime. ${ }^{87}$ These assertions work well by the reliance on the concept of fairness to justify anti-dumping measures, although the abstract nature of such a concept can lead to abuse. ${ }^{88}$

As observed above, the preamble to the WTO Agreement upholds the environment and its sustainability. It can arguably strengthen the legal justification

82 Id.

83 Stewart \& Brightbill, supra note 77 , at 38.

84 Cass \& Boltuck, supra note 77, at 395-401.

85 E. Alben, GATT and the Fair Wage: A Historical Perspective on the Labor-Trade Link, 101 Colum. L. Rev. 1417 (2001); C. Fletcher, Greening World Trade: Reconciling GATT and Multilateral Environmental Agreements within the Existing World Trade Regime, 5 J. Transnat'L L. \& Pol’y 371 (1996).

86 Alben, id.

87 Fletcher, supra note 85.

88 E.g., the term 'unfairness' may need differing application as between countries which can compete fairly due to natural advantages such as being endowed with natural resources or favorable climatic conditions and countries which do not because they merely bank on artificial advantages such as market entry barriers. By right, the notion of unfairness should be used only in the second situation. For details, see D. Wood, Unfair Trade Injury: A Competition-Based Approach, 41 StAN. L. Rev. 1172-1173 (1989), recited from Cass \& Boltuck, supra note 77, at 358. 
of social or environmental dumping especially in its use against imports of biofuel products which are produced and processed in an unsustainable way. ${ }^{89}$ The US has used both social (labor) and environmental concerns to justify the imposition of anti-dumping duty in Shrimp and Prawns from Brazil, China, Ecuador, India, Thailand and Vietnam case. ${ }^{90}$ In the case, the United States International Trade Commission ("USITC") considered the environmental concerns both over lenient rules regarding the release of effluents from shrimp farms, and over the less expensive costs in the countries subject to anti-dumping duties. ${ }^{91}$ Also, such considerations would help determine the existence of dumping in those countries.

Regarding the social or environmental justifications, however, the Shrimp case does not clearly indicate that social and environmental standards are part of the WTO anti-dumping regime. The elaborate rules (both substantive and procedural) within such a regime do not address the issue of social and environmental dumping resulting from labor and environmental standards which correlate with "belownormal-value pricing." ${ }^{92}$ As discussed, the existence of dumping can be determined either on the basis of a price differential (the export price being lower than the home price) or below cost pricing. Nonetheless, the place for unsustainable production is not clear yet.

Perhaps the advantage of unsustainable production enjoyed by the dumping country can be quantified and applied in the construction of cost, below which a sale will constitute dumping. In other words, an additional element is placed on top of the existing production cost, selling, general and administrative costs ("SG\&A") and profits so that dumping may be found more likely. ${ }^{93}$ Considering the problems associated in the way of allocating the cost determining dumping, ${ }^{94}$ however, the social and environmental factors will add to existing complexities. Further, given that the importing country can easily construct these costs and profits, it would be rather arbitrary to decide dumping of imports from developing countries with low environmental and labour standards.

M.-P. Lanfranchi, Socio-economic Rights in Applicable International Trade Law, 8 L., DemocRACY \& DEv. 56 (2004), available at http://www.saflii.org/za/journals/LDD/2004/4.pdf (last visited on Apr. 6, 2014).

90 Certain Frozen or Canned Warmwater Shrimp and Prawns from Brazil, China, Ecuador, India, Thailand, and Vietnam, US International Trade Commission Investigations Nos. 731-TA-1063-1068 (Final), Publication 374 (Jan. 2005 ), available at http://www.usitc.gov/publications/701_731/pub3748.pdf (last visited on Apr. 6, 2014).

91 Id. at II-4.

92 Supra note 89 , at 54.

93 Anti-Dumping Agreement art. 2.2.

94 A. Bentley \& A. Silberston, Anti-Dumping and Countervailing Action: Limits Imposed By Economic and Legal THEORY 62-64 (2007). 
It is also ambiguous as to whether the scope of injury within the WTO antidumping regime goes beyond economic factors deleteriously affecting domestic industry. Here, social and environmental factors are not counted as an integral part of 'injury,' although such factors can still affect them as well as other elements in the importing country. In other words, injury in the anti-dumping regime is only that which is suffered by the domestic producer in the importing country, not in terms of environmental degradation or low labour standards in the dumping country.

Therefore, it would be difficult to use the anti-dumping regime to penalise importers of biofuels from countries like Malaysia, Indonesia and Brazil, unless such imports are sold below normal value. In Shrimp, although environmental concerns were highlighted in the proceeding, USITC made its determinations purely on economic grounds. In fact, despite the US measure in US-Shrimp being subject to the WTO Dispute Settlement Body, the basis of complaints (by Thailand) did not include the relevant environmental and social concerns. ${ }^{95}$

The action taken by the European Community ("EC") against imports of biodiesel from the US (Biodiesel from the US) highlights the same trend. Investigation was initiated against the imported biodiesel in 2008 which was subsidised by the US government. In March 2009, the EU found all the elements that allow imposition of anti-dumping duties against such imports. In July of the same year, a definitive anti-dumping duty was finally imposed. ${ }^{96}$ Though environmentalists hailed the decision as a positive move against "biofuel trading scam," 97 the EU Commission clearly stated that the anti-dumping proceeding was not linked to the EU's broader environmental policies in the area of biofuels. ${ }^{98}$

While anti-dumping determinations under the WTO system are purely economic, such a system considers mainly the interests of domestic producers. The WTO AntiDumping Agreement does not provide for a cost-benefit analysis that can be realized through an investigation for public interests, a platform for the consideration of

95 One of the grounds of claim was that the practice of zeroing by the US in calculating the dumping margins violated the WTO Anti-Dumping Agreement. It was held by the Panel and was later affirmed by the AB that such practice violated WTO rules. See Panel Report, US-Measures Relating to Shrimp from Thailand, WT/DS343/R (Feb. 29, 2008); Appellate Body Report, US-Measures Relating to Shrimp from Thailand, WT/DS343/AB/R (July 16, 2008).

96 See Biodiesel from the US [imposition of definitive anti-dumping duty] OJ 2009 L179/26 (Reg. 599/2009). See also T. Macalister, Demands for crackdown on biofuels scam: US 'splash and dash' loophole undermines climate change fight, The Guardian, Apr. 1, 2008, available at http://www.guardian.co.uk/environment/2008/apr/01/biofuels.energy (last visited on Apr. 6, 2014).

97 Id.

98 See European Commission, Trade: Anti-dumping, available at http://ec.europa.eu/trade/issues/respectrules/anti dumping/pr130608_en.htm (last visited on Apr. 6, 2014). 
wider implications of anti-dumping measures including the environment. ${ }^{99}$ The EC anti-dumping jurisprudence shows that it is possible even though the outcomes of public interest consideration do not clearly manifest in the final deliberations of the relevant EC anti-dumping authorities. ${ }^{100}$ However, in Biodiesel from the US, the environment issue did not arise in the Community interest deliberations. The only issue raised by the interested parties in the case was the possible impact of the antidumping measures in shifting trade flows, i.e., a switch from countries not covered by the measures, because the Community (domestic) producers had to depend on cheap soybean oil and palm oil as compared to the more expensive rapeseed oil. ${ }^{101}$

A more recent trend can be seen in the Biodiesel from Argentina and Indonesia case. ${ }^{102}$ This trend is reflected in the use of anti-dumping measures particularly by the EU against biofuel imports coming from countries which maintained differential export tax regimes (Indonesia and Argentina). ${ }^{103}$ Such regimes impose higher export tax on raw materials (soybean) than those on biofuel products (bioethanol/ biodiesel). ${ }^{104}$ It goes without saying that foreign purchasers, particularly from developed countries, could offer a better price for the raw materials. Without such a differential export tax regimes, the producers of raw materials in the exporting countries would not sell their products to the biofuel industry. Thus, developing countries such as Indonesia and Argentina would take measures to prevent shortages of supplies or increases of prices in respect of the raw materials. Nevertheless, according to the anti-dumping investigation by the EU on the biofuel imports from both countries, the beneficiaries of such measures in developed countries claimed that the dumping existed merely based on the prices of biodiesel which were lower than those of biofuel raw materials. ${ }^{105}$ In fact, on November 19 , 2013, the EU anti-dumping authority made an affirmative decision on dumping;

99 See EC anti-dumping decision in Compact Fluorescent Lamps from PRC [imposition of provisional duty], OJ 2001 L38/8 (Reg. 255/2001), available at http:/theses.gla.ac.uk/1854/1/2003qianphd.pdf (last visited on Apr. 9, 2014).

100 See Extramet v. EC Council [1992] ECR I-3813; [1993] 2 CMLR 619 ECJ (Case C-358/89). See also Compact Fluorescent Lamps from PRC [imposition of provisional duty], OJ 2001 L38/8 (Reg. 255/2001); Calcium Metal from People's Republic of China and Russia [imposition of definitive duty], OJ 1994 L270/27 (Reg. 2557/94); and Leather Footwear from PRC and Vietnam [imposition of definitive duties], OJ 2006 L275/1 (Reg. 1472/2006).

101 See Biodiesel from the US, [imposition of definitive anti-dumping duty] \ 168, OJ 2009 L179/26 (Reg. 599/2009).

102 See Biodiesel from Argentina and Indonesia, [notice of initiation of anti-dumping proceeding] OJ 2012 C260/08.

103 Id. $₫ 3$.

104 A. Bouët, C. Estrades \& D. Laborde, Differential Export Taxes along the Oilseeds Value Chain, IFPRI Discussion Paper 01236, Dec. 2012, at 8, available at http://www.ifpri.org/sites/default/files/publications/ifpridp01236.pdf (last visited on Apr. 6, 2014).

105 See European Biodiesel Industry reacts against dumped imports from Argentina and Indonesia, Press Release by European Biodiesel Board, Aug. 30, 2012, available at http://www.ebb-eu.org/EBBpressreleases/Notice\%20of\%20 Initiation\%20August2012.pdf (last visited on Apr. 6, 2014). 
injury and causation led to the imposing of the final anti-dumping duties against Argentina and Indonesia ranging from $8.8 \%$ to $25.7 \%{ }^{106}$

\section{Anti-Subsidy Policies}

One of the main concerns arising from biofuel production and trade is the 'subsidies' to biofuel producers. The WTO regulates the subsidies in the biofuel industries through the Agreement on Agriculture ("AoA") regime and the Subsidies and Countervailing Measures ("SCM") regime. Different regimes apply to bioethanol and biodiesel because of the lack of a single comprehensive regulatory measure on biofuel trade. AoA applies to bioethanol, whereas SCM to biodiesel. Both the AoA and SCM regimes would prohibit the governments of the WTO Members from allowing a productive advantage to producers including to those of bioethanol and biodiesel.

Before analysing the approach taken by both regimes, the general categorisation of domestic support measures in agriculture needs to be understood. ${ }^{107}$ Domestic support measures are used by governments to assist agricultural producers including those who produce bioethanol. AoA, however, recognizes two categories of support - amber box and green box support measures. ${ }^{108}$ The amber box measures are trade-distorting. ${ }^{109}$ An example of such a measure is a government policy that provides payments to agricultural producers to produce a type of crops to a certain level. Such a policy also allows the subsidisation of prices so that consumers pay less than what the producers offer. AoA does not prohibit such measures completely. Rather, it requires a WTO Member to commit to a certain maximum level of support which is known as the aggregate measurement of support (“AMS”). ${ }^{110}$ No WTO Member can permit their total AMS to exceed the corresponding annual or final bound commitment level that it has already made. This level is specified in the Member's Agriculture Schedule of Commitments. ${ }^{111}$

\footnotetext{
106 See Biodiesel from Argentina and Indonesia [imposition of final duty] 9 215, OJ 2013 L 315/2 (Reg. 1194/2013), available at http://www.bloomberg.com/news/2013-11-19/argentina-indonesia-hit-with-eu-tariffs-on-biodiesel.html (last visited on Apr. 9, 2014).

107 Harmer divides these measures into the following four elements: (1) output-related assistance; (2) support for factors of production; (3) downstream subsidies; and (4) support for distribution and use. See T. Harmer, Biofuel Subsidies and the Law of the WTO, ICTSD Issue Paper No. 20 (2009), at 8-11, available at http:/ictsd.org/downloads/2012/03/ biofuels-subsidies-and-the-law-of-the-wto.pdf (last visited on Apr. 9, 2014).

108 Id. at 7.

109 Id.

110 AoA art . 6(1).

111 Id. art. 6(4).
} 
The green box measures, on the other hand, must neither involve tradedistortion, nor transfers from consumers who would have to pay more for raw materials because the subsidy requires them to be produced in a certain way required by the government. ${ }^{112}$ There are also specific objectives for any measure of support to be "green box support" as follows: (a) general services; (b) food security; (c) domestic food aid; (d) direct payments to producers; (e) decoupled income support; (f) income insurance and income safety net programmes; (g) natural disaster relief; (h) producer retirement programmes; (i) resource retirement programmes; (j) investment aids; (k) environmental programmes; and (l) regional assistance programmes. ${ }^{113}$

The green box support measures are not part of WTO Members' AMS. Instead, the Members must notify their green box measures to the WTO. In 2009, e.g., Malaysia notified its green box support measures including general services. ${ }^{114}$ These services were as follows: (1) drainage and irrigation facilities; (2) marketing services for rural and smallholding farmers; and (3) research and development programmes. The list also comprises price subsidy and guaranteed minimum price ("GMP"). ${ }^{115}$ There is a fine distinction between the amber box and the green box supports. Although price subsidy and GMP may look like trade-distortion, they are not contingent upon the type and level of production to be undertaken by the farmers. In fact, they target paddy farmers in the context of their poverty redress and socio-economic well-being. The Malaysian measure is arguably in line with Article 6(2) of AoA, which provides that agricultural and rural assistance, and investment subsidies of the government for low-income and resource-poor producers are exempt from domestic support commitments by developing countries. ${ }^{116}$

The autonomy of the WTO Members in using subsidies to further environmental objectives is clearly recognized in WTO agreements. However, Members must seriously consider the invocation of other rationales including development, whose promotion is affirmed by specific provisions of AoA. At the same time, other WTO Members are not precluded from bringing a WTO action against the subsidising State, thereby opening the possibility of divergent perceptions over what amounts to a green box support. This suggests that though subsidies can be used to benefit

\footnotetext{
112 Supra note 107 , at 7.

113 AoA annex 2. See also supra note 107, at 7-8.

114 See Malaysia's Notification of its Domestic Support to the WTO Committee on Agriculture, G/AG/N/MYS/25 (Aug. 10, 2009).

115 Id.

116 AoA art. 6(2).
} 
biofuel production under the consideration of environmental protection, the tradedistortion requirement would remain intact.

AoA covers only bioethanol, because biodiesel is covered by SCM. While biodiesel is considered an industrial product, this status could still be debated as biodiesel is mostly derived from plants like oil palm.

The legal framework for the WTO SCM regime is built upon the Agreement on Subsidies and the Countervailing Measures [hereinafter SCM Agreement]. The SCM Agreement defines a subsidy as a "financial contribution by a government that gives its recipient an advantage in the marketplace." ${ }^{117}$ It also recognizes two types of subsidies - prohibited and actionable - for the purpose of legitimizing the use of countervailing measures against subsidies. ${ }^{118}$ A prohibited subsidy is contingent upon either export performance or the fulfilment of the local content requirement by which preference is given to local goods. ${ }^{119}$ An actionable subsidy, on the other hand, targets a specific enterprise or industry. It causes injury to a complaining WTO Member or serious prejudice to the interests of other WTO Members. ${ }^{120}$

The Biodiesel from the US is an example of a subsidy. ${ }^{121}$ The US gave tax credits to the relevant biofuel producers including to those outside the country. As the biodiesel imports from the US was tremendously increasing in the EU market, the Union finally imposed countervailing duties on those imports. ${ }^{122}$ Until the case is brought to the WTO dispute settlement body, the WTO-consistency of the subsidy or its legal status would not be clear. ${ }^{123}$

The SCM Agreement's allowance of 'green light' or permitted subsidies has expired. Before the year 2000, such a Member would have relied upon Article 8 of the SCM Agreement, which provides that subsidies are not actionable if they serve the following objectives: (1) research and development; (2) regional development; and (3) environmental protection. Unfortunately, the provision expired in the year 2000. The position may change as the result of the Doha Round which is still

117 SCM Agreement art. 1.1.

118 Id. art. 3 (the definition of prohibited subsidy) \& Pt. III (the definition of actionable subsidy).

119 Id. art. 3.

120 Id. art. 5.

121 See Biodiesel from the US (countervailing case) [imposition of definitive duty] OJ 2009 L179/1 (Reg. 598/2009); Biodiesel from the US (countervailing case) [imposition of provisional duty] OJ 2009 L67/50 (Reg. 194/2009).

122 See Biodiesel from the US (countervailing case) [imposition of provisional duty] ๆף 3 -5 \& $\uparrow \uparrow$ 174-182, OJ 2009 L67/50 (Reg. 194/2009).

123 The list of cases that cited the SCM Agreement in the request for consultations at the Dispute Settlement Body since 2009 does not show any request from the US over the countervailing measures used by the EU against its imports of biodiesel. See WTO, Disputes by Agreement, available at http://www.wto.org/english/tratop_e/dispu_e/dispu_ agreements_index_e.htm?id=A20 (last visited at Apr. 6, 2014). 
uncertain. ${ }^{124}$ Currently, however, if a complaining party can show that an industry is targeted and injury is suffered, an actionable subsidy would be found and the matter would proceed to the analysis of injury. This highlights the dual treatment given to bioethanol and biodiesel production under the WTO system.

\section{Framework for Developing Countries}

By the Special and Differential Treatment ("SDT") regime, developing countries can enjoy a special and favourable treatment from a developed country. The key provision here is the Enabling Clause ${ }^{125}$ which gives effect to Part IV of GATT providing for trade and development. But it falls short of establishing legally binding provisions. The Enabling Clause creates an exception to the MFN principle. It also allows preferential treatment to be given by developed countries to developing countries for tariffs as well as for differential and favourable treatment in respect of non-tariff measures. The Enabling Clause also permits the creation of regional or global arrangements among developing countries so that they could mutually reduce or eliminate tariffs and non-tariff measures. ${ }^{126}$

The Enabling Clause has so far created two mechanisms. One is the regional trade arrangement ("RTA") mechanism by which developed countries give certain quotas for the import of biofuels (particularly bioethanol) from selected developing countries in Africa, the Caribbean and the Pacific. The other is the generalised system of preferences ("GSP"), ${ }^{127}$ which has been used to confer tariff preferences to imports of biofuel products from some developing countries. ${ }^{128}$ The EC's GSP scheme, e.g., gave 15 percent reduction of an MFN duty to bioethanol imported from all GSP beneficiary countries unless they have 'graduated' and the scheme lasted till

124 It must be noted that though the provision expired, the issue of non-actionable subsidies is subject to negotiations in the Doha Round. Thus, changes to the law are highly likely. See F. Ayala \& K. Gallagher, The Subsidies Agreement at the WTO, Paper on Preserving Policy Space for Sustainable Development, International Institute for Sustainable Development, Winnipeg, 2005, at 8, available at http://www.iisd.org/pdf/2005/communities_eiz_guide.pdf (last visited at Apr. 9, 2014).

125 GATT Contracting Parties, Decision of November 28, 1979 on Differential and More Favorable Treatment, Reciprocity, available at http://www.fas.org/sgp/crs/misc/RS22183.pdf (last visited at Apr. 9, 2014)

126 Enabling Clause 2(c).

127 The arrangements entered into by the US include the US-Caribbean Basin Initiative ("CBI"), the Andean Pact and the Central American Free Trade Agreement ("CAFTA") while the well-known arrangement entered into by the EU is the Cotonou Agreement which provides preferential treatment to ACP countries. See supra note 8, at 34-35.

128 Supra note 8, at 34. 
the end of 2005. ${ }^{129}$ A new scheme known as the GSP+ was drafted giving 100 percent reduction to bioethanol imports from 'vulnerable' countries practicing a sustainable development model and good governance. ${ }^{130}$ From January 1, 2008 to December 31, 2011, such preference has been given to the following countries - Bolivia, Colombia, Costa Rica, Ecuador, Panama, Peru, El Salvador, Venezuela, Georgia, Sri Lanka and Mongolia. $^{131}$

Looking at the two mechanisms, the main reason for such a preference may either be the unfavourable economic condition of the beneficiary countries, or the low income of these countries. Developing countries producing mass biofuel like Malaysia, Indonesia and Brazil may thus be excluded from the GSP scheme because they have already graduated. On the contrary, both the US and EU GSP schemes have been extended to some Andean countries which may not be classified as lowincome developing countries (Venezuela and Colombia). Even so, it has been argued that the benefits of trade preferences to developing countries may be minimal and the costs of those preferences "can vastly outweigh" their benefits as they could be used as "bargaining chips and are subject to non-trade related conditions."

Meanwhile, the position of developing countries in relation to the use of nontariff measures can be defined by the SDT provisions in the WTO treaties providing for measures such as the TBT Agreement ${ }^{133}$ and the Anti-Dumping Agreement. ${ }^{134}$ However, the effectiveness of such provisions in improving the position of developing countries vis-a-vis the use of such measures is under doubt. Both the TBT and the Anti-Dumping Agreements have the SDT provisions, but their scope is limited to capacity building. Further, they are either inapplicable or do not create specific obligations on developed countries. ${ }^{135}$

Regarding anti-subsidy policies, however, the SDT provisions seem to offer more concrete solutions to the least developed countries. The SDT provisions in AoA

\footnotetext{
129 Id.

130 See EC Council Regulation 732/2008 of 22 July 2008, OJ L 211 (Aug. 6, 2008), at 1, recited from supra note 8, at 34.

131 See EC Commission Decision 2008/938/EC, OJ L 334 (Dec. 12, 2008), at 90, recited from supra note 8, at 34.

132 S. Alam, Economic Globalization: Rethinking its Promises for Economic and Social Development from a Developing Country Perspective, in Globalization and the Quest for Social and Environmental Justice 84 (S. Alam, N. Klein \& J. Overland eds., 2011). Noticeable is that Alam highlighted the costs of trade preferences in a general term where he did not specifically allude to biofuel trade of the developing countries.

133 TBT Agreement art. 12.

134 Anti-Dumping Agreement art. 15.

135 Panel Report, US - Anti-Dumping and Countervailing Measures on Steel Plate from India 9 7.111, WT/DS206/R (June 28, 2002). This case explains the position for anti-dumping policy. As regards TBT, the WTO jurisprudence is yet to interpret such provisions and this signifies the non-applicability of those rules as between a developing and a developed country.
} 
exempt the least-developed countries from all subsidy reduction commitments, while other developing countries are entitled a grace period for the implementation of the agreement of up to 10 years. ${ }^{136}$ The SDT provisions in the SCM Agreement are more detailed. As discussed in the previous section, they permit the least developed countries the option of prohibited subsidies, particularly relating to export, although there is a clear condition for reducing them gradually. ${ }^{137}$ However, such special and differential treatment is not available to major biofuel producers among the developing countries.

\section{Conclusion}

There is no specific regulatory framework for trade in biofuels particularly within the WTO system. However, this does not mean that the restrictions of biofuel imports are not subject to the existing rules under the available system. In the context of imports from developing countries, the use of tariffs and non-tariff measures like TBT and anti-dumping, is regulated by the WTO treaties based on general principles like the National Treatment, MFN and SDT principles. Social and environmental questions are central to the attempts by developed countries in restricting the import of biodiesel and bioethanol from certain developing countries when production affects the environment and human rights, especially the right to health.

This article finds that the TBT regime has a strong justification as a policy option within the WTO system. The social and environmental impact of production and export of biofuels from these countries could fit in the legitimate objectives of the TBT measures. It is dangerous in that such a regime is not capable of addressing both the highly contentious issue of costs and benefits of tropical biofuels, and the blurred origin of a biofuel product. The anti-dumping policy can hardly be a better policy option unless a social and environmental content is introduced to the WTO antidumping substantive rules. So far the WTO Members have been practicing, by pure economic consideration, the anti-dumping policy. In the meantime, tariff peaks and tariff escalations are mechanisms which should be subject to review in negotiations at both bilateral and multilateral levels. The HS regime should also be subject to revision so as to create a new product classification for biofuel products. The lack of

136 AoA art. 15(2).

137 SCM Agreement art. 27.3. 
this classification has led to the dual treatment of bioethanol and biodiesel with the former being regulated by the AoA regime, while the latter being subject to the SCM regime.

In toto, the WTO rules in relation to biofuel production and trade need to be revisited in order to ensure that the restrictions on biofuel imports from developing countries will truly serve social and environmental objectives rather than turning into protectionist tools. 